\title{
Drivers and Spatial extent of Urban Development in Flood-prone Areas in Metropolitan Lagos
}

\author{
Bolanle Wahab ${ }^{1} \&$ Saeed Ojolowo ${ }^{1}$ \\ ${ }^{1}$ Department of Urban and Regional Planning, Faculty of Environmental Design and Management, University of \\ Ibadan, Ibadan, Nigeria \\ Correspondence: Bolanle Wahab, Department of Urban and Regional Planning, Faculty of Environmental \\ Design and Management, University of Ibadan, Ibadan, Nigeria. Tel: 234-807-991-7354. E-mail: \\ bolanle_wahab@yahoo.com
}

Received: February 4, 2018

Accepted: February 22, $2018 \quad$ Online Published: March 30, 2018

doi:10.5539/jsd.v11n2p98

URL: https://doi.org/10.5539/jsd.v11n2p98

This work was supported by the Coastal City at Risk Project (CCaR) with grant number [106372-011].

\begin{abstract}
Urban development in flood-prone areas has created many environmental challenges in many cities in Nigeria. This survey-based study examined the drivers and spatial extent of development in floodplains in metropolitan Lagos. A total of $1,031(7.2 \%)$ buildings out of 14,273 were systematically selected along 211 streets out of 1,403 prone to flood, and a structured questionnaire was administered to heads of households to determine the factors influencing development in floodplains. A Thematic Mapper of 1990, Enhanced Thematic Mapper of 2000 and the Google Earth Landsat of 2014 were also analysed in ILWIS 3.3 Academic and Arc-GIs 10.2 to determine the extent of development in floodplains. The study revealed, in order of significance, closeness to place of work, nearness to market, closeness to children's schools, low rent, low income, and family affinity as factors that influenced the development in floodplains in the Lagos metropolis. Ineffective control of development and inadequate compliance with planning and building regulations were additional factors. Urban development in flood-prone areas in Lagos increased from $9.3 \mathrm{~km}^{2}$ in 1990 to $10.50 \mathrm{~km}^{2}$ in 2000 and $17.80 \mathrm{~km}^{2}$ in 2014. The study recommends that floodplains should be acquired and effectively protected to prevent any form of physical development; they should serve as natural sink for storm water and urban green for passive recreation. Urban development regulations should be strictly enforced by the relevant government agencies, such as the Lagos State Building Control Agency in the Ministry of Physical Planning and Urban Development.
\end{abstract}

Keywords: drivers, urban development, floodplains, Lagos metropolis

\section{Introduction}

It is estimated that the urban population will rise from 3.57 billion in 2010 to 6.34 billion in 2050, with almost 70 per cent of the world population is expected to live in cities (United Nations, 2014). This growth is as a result of migration from rural to urban areas in search of better quality of life generated by urban activities and services (Deng, Wang, Hong, \& Qi, 2009). The increasing population of urban dwellers is one of the causes and indicators of urban development. Urban development is the development or improvement of an urban area in terms of number of building constructions (Collins English Dictionary, 2014). It occurs by expansion into unpopulated areas and/or the renovation of decaying regions (Brooks, 2014). For most cities, the transformation of land use is required to meet the needs of life and economic development (Hsiang-Leng, Hsing-Fu, \& Ko-Wan, 2013). However, lack of or inadequate implementation of urban development policies and regulations has led to the indiscriminate development of buildings (such as residential, industrial, recreational, commercial, religious, public and semi-public) in floodplains without recourse to urban development regulations. Development in floodplains is one of the causes of flooding in coastal cities. Flood usually occurs when a river or lagoon spills its excess water over the banks and runs into adjoining low-lying lands (Ijigah \& Akinyemi, 2015).

The severity of the impact of flood is compounded by sea level rise, rapid population growth, urbanization and increased rainfall intensity and frequency related to alterations in climate distribution (Nkwunonwo, 2017). As the coastal cities of Africa expand, many of their residents are pushed to the edges of available land space and 
some into the most hazardous zones (Boamah et al., 2015). Concentration of human population in urban settlements, without considering salient and relevant ecological factors aggravates flooding. Construction of buildings restricts runoffs, by covering large parts of the ground with roofs, roads and pavements, and obstructing sections of natural channels and drains that ensure that water moves to rivers faster than it does under natural conditions (Action Aid, 2006). Oni (2003) asserts that, when rainfall intensity exceeds the infiltration capacity of the soil, excess water is generated. The impervious human-made surfaces that make up the urban fabric ensure that little of the falling rain infiltrates into the ground (Ayoade, 2006). When it rains, some of the water is supposed to be retained in ponds or soil, by grass and vegetation, while the rest travels over the land as surface runoff. The removal of these water-retaining features, owing to urban development, increases impermeable surfaces that facilitate excessive runoff, causing siltation and blockage of hydraulic facilities, which eventually leads to flooding.

From 2010 to 2015, 57 disastrous flood events were recorded in West Africa with 1,169 fatalities Africa (Ouikotan, et al., 2017). From the early 1970s and possibly to date, floods have been responsible for building collapse, destroying property, and affecting more than 300,000 people in Lagos (Etuonovbe, 2011). Akanni and Bilesanmi (2011) report how a Lagos flood forced communities in Lagos to relocate because of heavy torrential downpour of 7th and 8th of July, 2011. Yet, residents continue to develop and live in flood-prone areas. So the areas are experiencing continuous flooding like that of July, 2017, which ravaged high-brow areas of Ikoyi, Lekki and Victoria Island. Previous studies (Taiwo, 2009; Etuonovbe, 2011; Adelekan, 2012; Aderogba, 2012) examined the overall spatial development of Lagos, without providing information about the characteristics of structures and factors influencing development within floodplains. This prompted the search for possible drivers, and also the spatial extent of development within floodplains in metropolitan Lagos, with a view to identifying sustainable solutions.

\section{Locational, Demographic and Spatial Traits of Lagos State}

Lagos State was created on May 27, 1967 when Nigeria was restructured into 12 states. Before this period, Lagos municipality was under the administration of the Federal Government, through the Federal Ministry of Lagos Affairs, as the regional authority. The city of Lagos was then under the Lagos City Council. The regions of Ikeja, Agege, Mushin, Ikorodu were under the former Western Region. Lagos State lies approximately between longitude $2^{0} 42^{\prime} \mathrm{E}$ and $3^{\circ} 42^{\prime} \mathrm{E}$ and latitude $6^{0} 22^{\prime} \mathrm{N}$ and $6^{0} 52^{\prime} \mathrm{N}$. The state is located on the south-western part of Nigeria, with the southern boundary of the state framed by about 180 kilometres of stretch of land along the Atlantic coastline, while the northern and eastern boundaries are framed by Ogun State. Republic of Benin formed the western boundary. The state is the smallest state in Nigeria in land area, covering about 358,861 hectares or $3577 \mathrm{sq} . \mathrm{km}$ (Odumosu, 1999). This represents only $0.4 \%$ of the entire area of the country. The state is also the most urbanised in Nigeria (UN-HABITAT, 2015). Only about $5.0 \%$ of the state total population is of rural areas. This has serious consequences on land use planning in the state, especially in urban areas, where residents continue to build on floodplains. The implications and consequences of this practice manifest in incessant environmental challenges, such as flooding, coastal erosion, improper waste management, insufficient storm drainage, housing collapse and land subsidence.

The Lagos metropolis had about 25,000 people in 1866 (Ayeni, 1981). The population grew to 40,000 in 1901 owing to the arrival of earlier refugees from slavery and war in the interior, freed slaves from Brazil, and later colonial administrators and traders who settled in the port. It reached 74,000 by 1911 ; and by 1963 , it was 665,000 (Abiodun, 1997). The provisional results of the 1991 and 2006 population censuses gave the Lagos metropolis a population of 5,294,774 million (or $93.0 \%$ of the total population of Lagos State) and 8,048,430 million, respectively (NPC, 1991; 2006). According to United Nations Department of Economic and Social Affairs, Population Division (2006), the population of Lagos State was 1.9 million in 1975; 8.4 million in the year 2000; 10.9 million in 2005; and 16.1 million in 2006. It projected the population to $20,662,902$ and $21,324,114$ in 2014 and 2015, respectively. Spatially, while the metropolis occupies $1,171.28 \mathrm{~km}^{2}$ only about $0.4 \%$ of the Nigerian land area, it harbours $6.43 \%$ of the nation's population. Also, while it occupies $40.0 \%$ of the land area of Lagos State, about $91.5 \%$ of the population of the state resides in it (The Lagos State Government, 2014). Metropolitan Lagos is located in a lowland, and about $220.6 \mathrm{~km}^{2}(23.2 \%)$ of the metropolis is made up of water bodies, wetlands and mangrove swamps (Lagos State Government, 2014). These traits have exposed the population and assets to the risks of flooding in Lagos City.

Spatially, Lagos City grew from a traditional core settlement of about $3.85 \mathrm{~km}^{2}$ in 1881 to $46.6 \mathrm{~km}^{2}$ in 1911 (Okude \& Ademiluyi, 2006). The city covered $52.3 \mathrm{~km}^{2}$ in $1921,66.3 \mathrm{~km}^{2}$ in 1931 , and $69.9 \mathrm{~km}^{2}$ in 1952 (Abiodun, 1997). By 1984, Lagos City had engulfed neighbouring towns and villages, and metropolitan Lagos encompassed about $85.44 \mathrm{~km}^{2}$ in 1986, $96.53 \mathrm{~km}^{2}$ in 1990 (Abiodun, 1997), and $950.72 \mathrm{~km}^{2}$ in 2006 (NPC, 2010; 
Lagos State Government, 2014). The spatial growth of Lagos State from 1984 to 2010 is presented in Figure 1 (Adelekan, 2012).

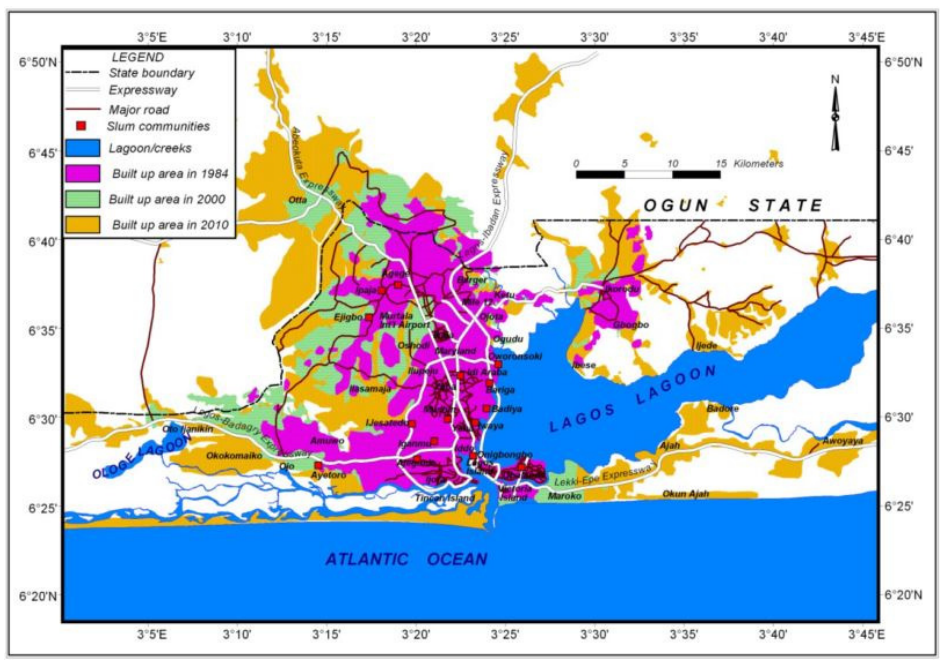

Figure 1. Urban development (1984-2010) in Lagos State

Source: Adelekan (2012)

\section{Methodology}

Primary and secondary data were employed to analyse the factors responsible for continual development and the extent of spatial development in flood-prone areas in metropolitan Lagos. Cross-sectional survey research approaches were adopted to obtain primary data sourced through the use of a structured questionnaire and physical observations. The questionnaire covered socio-economic and demographic characteristics of households, housing characteristics and reasons for building in flood-prone areas. The simple random technique was employed to select 211 of the 1,403 streets prone to flooding in the Lagos metropolis (Table 1). Yamane's (1967) model with the desired level of precision of 0.03 was used to calculate the number of sampled buildings, 1,031 (7.2\%) out of 14,273 buildings found in the study area. The systematic random sampling technique was used to select the 1,031 buildings where a structured questionnaire was administered to heads of households. Out of the 1,031 copies of the questionnaire administered, only 1,025 were adequate for analysis.

Table 1. Sample frame and size

\begin{tabular}{|c|c|c|c|c|c|c|}
\hline S/No. & LGAs & $\begin{array}{ll}* \text { No. of } \\
\text { streets }\end{array}$ & $\begin{array}{l}\text { *No. of streets } \\
\text { prone to flooding }\end{array}$ & $\begin{array}{l}\text { *No. of selected streets } \\
\text { prone to flooding }\end{array}$ & $\begin{array}{l}\text { *No. of houses on } \\
\text { selected streets }\end{array}$ & $\begin{array}{l}* * \text { No. of } \\
\text { houses sampled }\end{array}$ \\
\hline 1 & Agege & 1095 & 196 & 14 & 587 & 42 \\
\hline 2 & Ajeromi-Ifelodun & 391 & 70 & 11 & 620 & 45 \\
\hline 3 & Alimosho & 890 & 159 & 13 & 1121 & 81 \\
\hline 4 & Amuwo-Odofin & 119 & 21 & 10 & 860 & 62 \\
\hline 5 & Apapa & 191 & 34 & 14 & 656 & 47 \\
\hline 6 & Eti-Osa & 275 & 49 & 13 & 582 & 42 \\
\hline 7 & Ifako-Ijaye & 133 & 24 & 17 & 994 & 72 \\
\hline 8 & Ikeja & 419 & 75 & 13 & 525 & 38 \\
\hline 9 & Kosofe & 181 & 32 & 10 & 528 & 38 \\
\hline 10 & Lagos Island & 279 & 50 & 10 & 676 & 49 \\
\hline 11 & Lagos Mainland & 301 & 54 & 14 & 813 & 59 \\
\hline 12 & Mushin & 719 & 129 & 17 & 691 & 50 \\
\hline 13 & Ojo & 242 & 43 & 10 & 4177 & 302 \\
\hline 14 & Oshodi-Isolo & 1054 & 187 & 17 & 381 & 28 \\
\hline 15 & Shomolu & 1065 & 190 & 17 & 601 & 43 \\
\hline \multirow[t]{2}{*}{16} & Surulere & 503 & 90 & 11 & 461 & 33 \\
\hline & Total & 7857 & 1403 & $* 211$ & $* 14,273$ & $* * 1,031$ \\
\hline
\end{tabular}


The starting point was randomly selected by using the table of random numbers. To determine the sampling interval, the number to be sampled was divided by the number of houses in each street. The primary data obtained were analyzed with descriptive statistical models, while frequencies and percentages were used to present the data. Ethical issues were given due consideration, with regard to the purpose of the study, contents of the research instrument, acceptance of respondents' right to privacy, and confidentiality of the data; and the informed consent and willingness of the respondents to answer questions was obtained.

To analyse development in floodplain in the Lagos metropolis, three sets of images were used for this study: the Thematic Mapper of 1990, Enhanced Thematic Mapper of 2000 and the Google Earth Landsat of 2014. The images of 1990 and 2000 were downloaded from two different paths and rows (p190r056 and p191r055). The properties of the images are shown in Table 2. Bands 4,3,2, were used to form the false colour composite for this study. In these bands combination $(4,3,2)$ vegetation appeared in shades of red, urban areas in cyan blue and water surfaces appeared in blue. The images from the two different paths and rows (p190r056 and 191r055) were glued using the "Glue Raster Map Tool" on the operation list of ILWIS Academic 3.3 and the Area of interest (the Lagos metropolis) was "clipped out" using the X,Y Coordinates on the top right corner and X,Y Coordinates on the lower left corner. This task was also performed on ILWIS 3.3 Academic. The image of 2014 was downloaded on Google Application. Segments for water body, built-up area and vegetation were created on these images and each of these features (water body, vegetation and built-up area) was digitized on ILWIS 3.3 Academic. After the digitization of these features, their "segments" were polygonized so as to determine the area coverage of each of these features.

To ascertain the built-up area vulnerable to flooding, all the polygonized features were exported from ILWIS 3.3 Academic to Arc-GIs 10.2 software. A buffer of 50 metres (the designated setback for canals/lagoon) was created along the water ways. This operation was executed using the "Analysis Tool" on "Arc toolbox" and the option of proximity was selected. The built-up areas that fell within the buffer area were digitized, and areas of the vulnerable development were calculated.

Table 2. Properties of images

\begin{tabular}{cccc}
\hline S/No. & Image Year & Path and Row & Sensor \\
\hline 1 & 1990 & P190 R056 and P191 R055 & TM \\
2 & 2000 & P190 R056 and P191 R055 & ETM $^{+}$ \\
3 & 2014 & ----- & Google Earth \\
\hline
\end{tabular}

\section{Results and Discussions}

\subsection{Gender, Age Structure, Marital Status and Household Size of the Respondents}

Sixty-three per cent of the respondents were males, while $36.6 \%$ were females. The classification of age, as presented in Table 3, showed that $68.4 \%$ of the respondents were in the age group $30-39$ years, $16.4 \%$ were 40-49 years, $4.1 \%$ were $50-59$ years, $7.6 \%$ were $20-29$ years, while $3.5 \%$ were 60 years and above. This implies that the majority $(84.9 \%)$ of the people inhabiting the sampled flood-prone areas were within the age bracket 30-49 years, who were assumed to be contributing significantly to continuous development of flood-prone areas owing to their increasing demand for housing and associated infrastructure. The majority of the respondents (87.4\%) were married. The high percentage of married residents implies that the population of residents in flood-prone communities will continue to rise through birth and migration (couples attract more squatting families), leading to increasing demand for and construction of houses in more fragile parts of wetlands in the face of laxity in development control. On the size of households, the majority $(72.0 \%)$ had 3-6 members, $11.3 \%$ had more than 10, 9.7\% had 7-9 members, while 7.0\% had 1-2 members. By implication, the size of the households facilitated the trampling of the floodplains and subsequent hardened land surface made infiltration of water difficult and led to excessive surface runoff and then caused flooding.

\subsection{Educational Status, Occupation and Income Distribution}

The educational status of the respondents reflected the metropolitan nature of Lagos State, as all of them attended school. While $1.0 \%$ of the respondents indicated that they had primary school education, $71.9 \%$ had secondary school, and $27.1 \%$ had tertiary education, as shown in Table 3. These qualifications are expected to facilitate their knowledge and understanding of the implications of all forms of development in flood-plains and 
wetlands in their communities.

The various occupations indicated by the respondents are also presented in Table 3 . The study revealed that $39.5 \%$ were traders, $34.1 \%$ were artisans, while $15.3 \%$ were civil servants. About $4.8 \%$ engaged in farming, $3.0 \%$ mined sand, $1.4 \%$ engaged in fishing, $0.9 \%$ were retirees, while $1.0 \%$ were commercial bus-drivers. This indicates that the majority $(84.7 \%)$ of the inhabitants of the flood-prone areas were in the informal sector of the economy. More than half (51.4\%) earned $\$ 18,000$ and below monthly, $16.8 \%$ earned $¥ 40,000$ - $\$ 59,000 ; 15.2 \%$ earned $\$ 80,000$ - $\$ 99,000,11.7 \%$ earned $\$ 20,000-\$ 39,000,3.7 \%$ earned $\$ 100,000$ and above, while $1.2 \%$ earned $\$ 60,000$ - $\$ 79,000$ per month. This information showed that the majority (51.4\%) of the people living in flood-prone areas earned below the national minimum wage of $\$ 18,000$ per month (at the time of survey).

Table 3. Socio-economic and demographic characteristics of the respondents

\begin{tabular}{|c|c|c|}
\hline Socio-economic variables & Number of respondents & Percentage \\
\hline \multicolumn{3}{|l|}{ Highest Educational Status } \\
\hline Primary & 10 & 1.0 \\
\hline Secondary & 737 & 71.9 \\
\hline Tertiary & 278 & 27.1 \\
\hline Total & 1025 & 100.0 \\
\hline \multicolumn{3}{|l|}{ Occupation } \\
\hline Trading & 405 & 39.5 \\
\hline Fishing & 14 & 1.4 \\
\hline Farming & 49 & 4.8 \\
\hline Sand mining & 31 & 3.0 \\
\hline Civil service & 157 & 15.3 \\
\hline Artisan & 350 & 34.1 \\
\hline Retiree & 9 & 0.9 \\
\hline Commercial Bus Driving & 10 & 1.0 \\
\hline Total & 1025 & 100.0 \\
\hline \multicolumn{3}{|l|}{ Income range per month } \\
\hline$<18,000$ & 527 & 51.4 \\
\hline$N 19,000 \quad-\quad 39,000$ & 120 & 11.7 \\
\hline$N 40,000 \quad-\quad N 59,000$ & 172 & 16.8 \\
\hline N60,000 - $\quad$ 79,000 & 12 & 1.2 \\
\hline N 80,000 - 99,000 & 156 & 15.2 \\
\hline 100,000 \& Above & 38 & 3.7 \\
\hline Total & 1025 & 100.0 \\
\hline
\end{tabular}

\subsection{Residential Tenure and Structural Condition of Buildings}

The level of income of the respondents was reflected in the totality of their environment, particularly in the types of materials used for constructing houses, household facilities, and general conditions of the compounds. Of the respondents presented in Table 4, 23.7\% owned the buildings, $69.4 \%$ were tenants, while $6.9 \%$ were living with relations. The majority (60.6\%) of the buildings were Brazilian bungalows (90.9\%), followed by Brazilian storey (17.2\%); detached self-contained bungalows (11.3\%) and block of flats (10.9\%). The building types reported reflected the findings on household size and number of rooms. The buildings with 5-10 rooms were $71.4 \%$; $10.4 \%$ had $11-15$ rooms; while those with less than 5 rooms were $10.8 \%$; and only $7.4 \%$ had $16-20$ rooms (Table $5)$.

Information obtained about the age of the buildings indicated that people began to occupy the flood-prone areas since the last 50 years, and that occupation was more pronounced about the last 20 years, as indicated by $52.7 \%$ 
of the buildings (Table 4). This coincided with the period when the population of Lagos State grew from 5.3 to 7.9 million (67.9\%) in 1991 and 2006, respectively (NPC, 1991 and 2006). Those buildings that were constructed $20-29$ years ago were $43.7 \% ; 2.4 \%$ were built $30-39$ years ago, while only $1.2 \%$ was developed 40-49 years ago. The information obtained revealed that the occupation of flood-prone areas was an old, unabated phenomenon that continued into the present time, and was aggravating the exposure of the inhabitants of the Lagos metropolis to the risks of flood, as postulated by Hallegatte, Green, Nicholls, \& Corfee-Morlot (2013). The materials used to construct these buildings were also captured; they were indicative of poor earnings, as revealed in the residents' monthly income. For the walls, 2.2\% were made of plank (Plate 1), 12.4\% of concrete, $1.9 \%$ of wattle, $1.5 \%$ of corrugated iron sheets (Plate 2), and $80.2 \%$ of sandcrete blocks (Table 4 ).

Out of $15(100.0 \%)$ buildings whose walls were made of corrugated iron sheets, $80.0 \%$ were suspended in the lagoon, canal or wetland and had their floors made of plank, as illustrated in Plate 2. About $64.7 \%$ of the buildings had their floors made of mud with cement, while $34.1 \%$ had their floors made of cement concrete. Expectedly, the common roofing material was corrugated iron sheets, with $80.2 \%$ frequency, implying that almost all the buildings had corrugated iron sheet for their roof. About $12.2 \%$ of the buildings had their roofs made of slate; $2.5 \%$ had concrete roofs in anticipation of mounting another floor, while $5.1 \%$ had roofs made of sheet metal (Table 4).

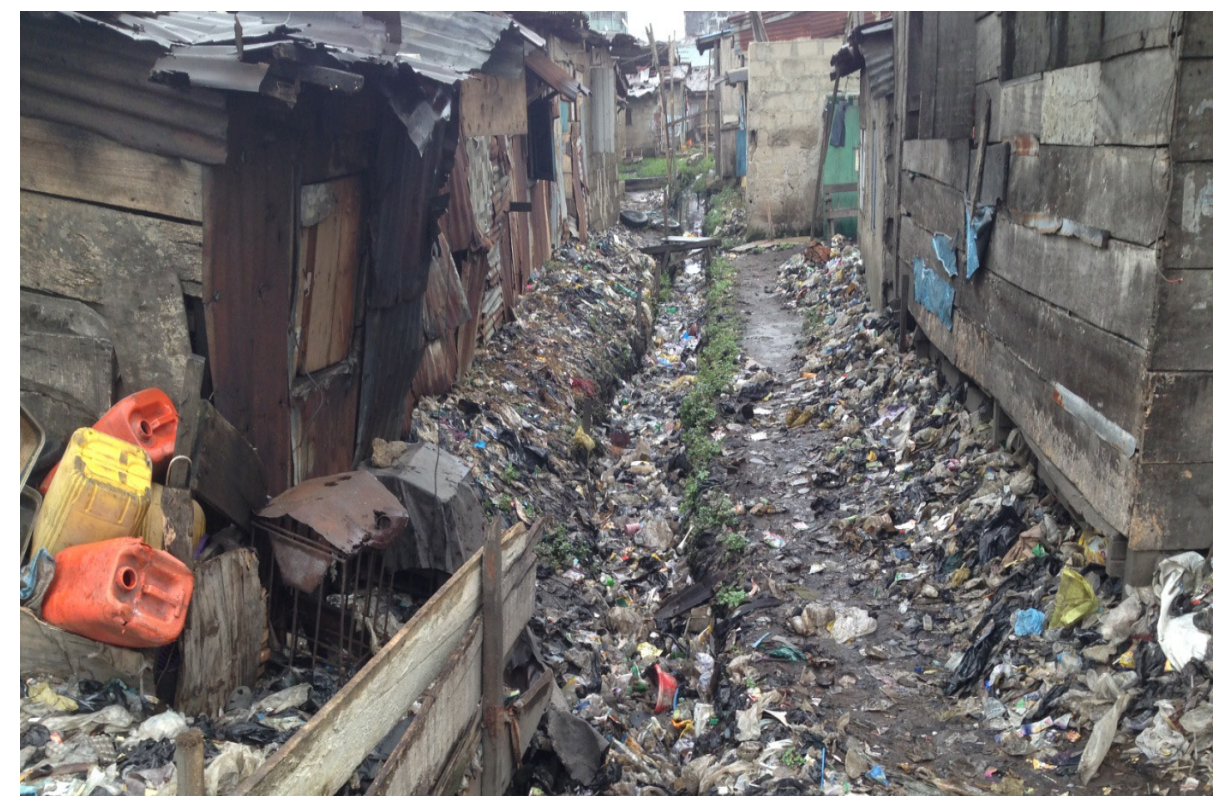

Plate 1. Residential buildings made of planks and corrugated iron sheets with the drainage blocked by solid waste at Ugbewankwo Lane, Ajeromi-Ifelodun LGA, Lagos State, Nigeria

(Note the building constructed with sandcrete blocks at the background) 


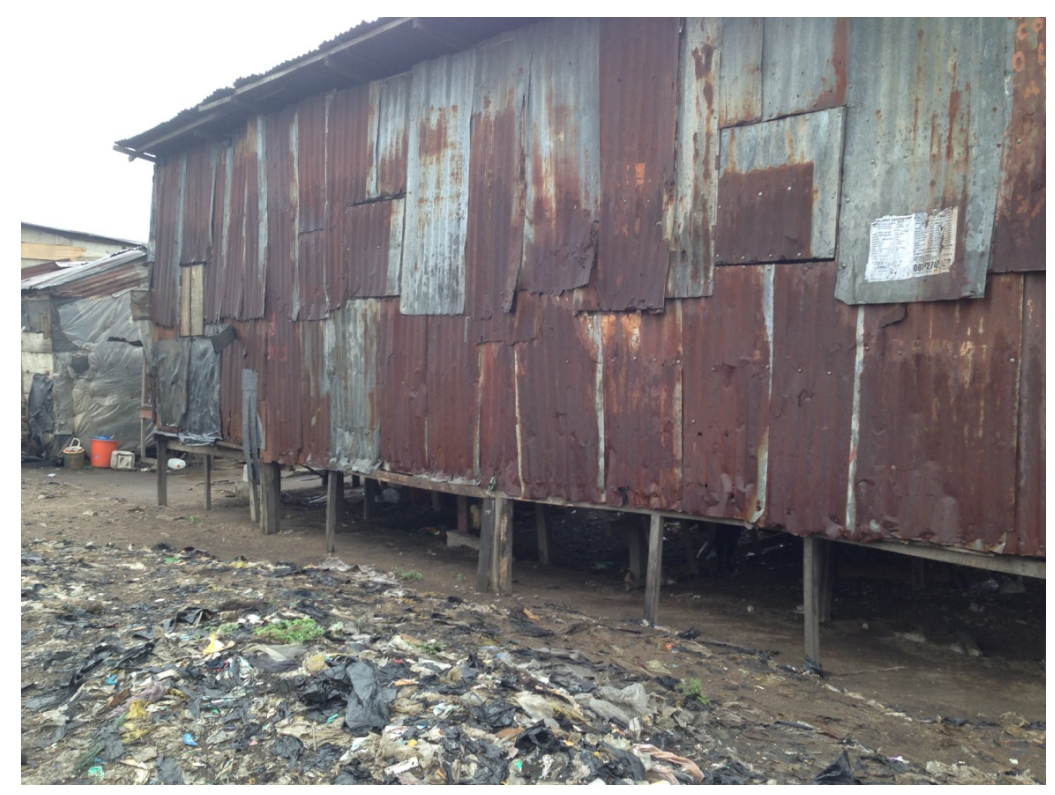

Plate 2. A typical residential building on stilt in a flood-prone area at Otto, Lagos Mainland LGA, Lagos State, Nigeria

Table 4. Residential tenure and characteristics of buildings

\begin{tabular}{lcc}
\hline Characteristics & No. of buildings & Percentage \\
\hline Residential Tenure & 243 & 23.7 \\
Owned & 711 & 69.4 \\
Tenant & 71 & 6.9 \\
Living with relations & $\mathbf{1 0 2 5}$ & $\mathbf{1 0 0 . 0}$ \\
Total & & \\
Building type & 116 & 11.3 \\
Detached Self-contained Bungalow & 621 & 60.6 \\
Brazilian Bungalow & 176 & 17.2 \\
Brazilian Storey & 112 & 10.9 \\
Block of Flats & $\mathbf{1 0 2 5}$ & $\mathbf{1 0 0 . 0}$ \\
Total & & \\
Age of building (year) & 540 & 52.7 \\
$<20$ & 448 & 43.7 \\
20-29 & 25 & 2.4 \\
$30-39$ & 12 & 1.2 \\
$40-49$ & $\mathbf{1 0 2 5}$ & $\mathbf{1 0 0 . 0}$ \\
Total & & \\
Materials used in constructing wall & 23 & 2.2 \\
Plank & 19 & 1.9 \\
Wattle & 127 & 12.4 \\
Concrete & 841 & 82.0 \\
Sandcrete blocks & 15 & $\mathbf{1 0 0 . 0}$ \\
Corrugated iron sheet & $\mathbf{1 0 2 5}$ \\
Total & &
\end{tabular}


The study also revealed that, in spite of the appalling conditions of the floodplains, the respondents had long years of residency. For instance, while only $3.2 \%$ of the sampled residents had been residing in the areas for more than 25 years, $0.6 \%$ had resided there for 21 to 25 years; $12.6 \%$ had lived in flood-prone areas for $16-20$ years; and $14.0 \%$ had been residing in the areas for between 11 and 15 years (Table 5). Surprisingly, 66.5\% of the respondents moved into the flood-prone areas in the last ten years, out of which only $3.1 \%$ of them moved into the areas in the last five years. This is an indication that the floodplains had continued to attract more residents notwithstanding the obvious high-level risks and the hazardous nature. It also suggests the general massive population inflow into Lagos for employment opportunities and social and infrastructural facilities available in the city. The unavailability of suitable, accessible and affordable plots of land close enough to areas of employment opportunities also contributed to the development of "shanty" structures for housing in areas that are prone to flooding in the metropolis of Lagos.

Table 5. Duration of living in the sampled communities

\begin{tabular}{rccc}
\hline S/No. & Duration (years) & Number of respondents & Percentage \\
\hline 1 & $<5$ & 32 & 3.1 \\
2 & $6-10$ & 682 & 66.5 \\
3 & $11-15$ & 143 & 14.0 \\
4 & $16-20$ & 129 & 12.6 \\
5 & $21-25$ & 6 & 0.6 \\
6 & $>25$ & 33 & 3.2 \\
& Total & $\mathbf{1 0 2 5}$ & $\mathbf{1 0 0 . 0}$ \\
\hline
\end{tabular}

\subsection{Reasons for Residing in Floodplains}

Furthermore, the reasons for residing in the floodplains in metropolitan Lagos were investigated. Table 6 shows that the most prominent factor in eight of the 16 LGAs was "closeness to place of work", ranked highest in Agege (21.5\%), Ajeromi-Ifelodun (18.8\%), Alimosho (16.8\%), Apapa (22.4\%), Eti-Osa (26.8\%), Ifako-Ijaiye (20.5\%), Lagos Island (22.9\%) and Lagos Mainland LGAs (17.8\%). Other factors that were ranked highest as influencing residents' choice of their residential areas were "closeness to children's school", in Lagos Mainland (17.8\%); "low rent", in Agege (21.5\%), Ajeromi-Ifelodun (18.8\%), Ifako-Ijaye (20.5\%), and Surulere LGAs (19.9\%); "nearness to market", in Amuwo-Odofin (42.0\%), Ikeja (27.3\%), Ojo (27.7\%) and Oshodi-Isolo LGAs (20.0\%); and "low income", in Apapa (22.4\%), Ifako-Ijaye (20.5\%), Kosofe (30.0\%), Mushin (19.3\%), and Shomolu LGAs (17.9\%).

The second most prominent factor identified by the respondents for their choice of residential location was still "closeness to place of work", as claimed by respondents in six of the sixteen LGAs: Amuwo-Odofin (30.8\%), Ikeja (19.1\%), Mushin (17.2\%), Ojo (20.7\%), Shomolu (17.5\%) and Surulere (18.5\%). Other factors ranked second in the various LGAs were "closeness to children's school", indicated by the respondents in Alimosho (14.7\%), Eti-Osa (25.5\%) and Oshodi-Isolo LGAs (19.6\%); "low rent", in Lagos Island (21.4\%), Mushin (17.2\%), Ojo (20.7\%) and Shomolu LGAs (17.5\%); "nearness to market", in Kosofe LGA (18.3\%); and "low income", in Oshodi-Isolo LGA (19.6\%).

Factors that were ranked the least as influencing respondents' residential choice in the study area, where they were rated at all, were "portion of family land", rated in Agege (4.0\%), Ajeromi-Ifelodun (1.6\%), Alimosho (2.2\%), Eti-Osa (2.2\%), Ifako-Ijaye (1.3\%), Lagos Island (4.0\%), Ojo (0.8\%), Shomolu (1.2\%) and Surulere LGAs (1.1\%); and, "well planned community" was rated in Apapa (1.4\%), Ikeja (1.5\%), Lagos Island (1.4\%), and Lagos Mainland LGAs (2.2\%) (Table 6).

The study has thus revealed the prominence of "proximity to work", "proximity to children schools", "proximity to market", and "economic situation" in that order as determinants of residential choice in flood-prone communities in the Lagos metropolis. The findings, especially in relation to proximity to place of work, was in conformity with earlier studies on the City of Chicago by Burgess (1923) and Harris and Ullman (1945), which observed the tendency of low-income earners to cluster in residence close to the central business district at the city centre where many of them work. Generally, significant factors, without considering the environmental conditions, before the decision to reside in floodplains were closeness to place of work (317.4\%), nearness to 
market (285.4\%), closeness to children's schools (270.4\%), low rent (258.4\%), low income $(251.0 \%)$, family affinity (196.1\%), and portion of family land (18.4\%).

Table 6. Reasons for living in flood-prone areas in Metropolitan Lagos

\begin{tabular}{|c|c|c|c|c|c|c|c|c|c|}
\hline $\mathbf{S} / \mathbf{N}$ & LGA & $\begin{array}{l}\text { Closeness } \\
\text { to place } \\
\text { of work } \\
\% \text { (Rank) }\end{array}$ & $\begin{array}{l}\text { Nearness } \\
\text { to market } \\
\%(\text { Rank) }\end{array}$ & $\begin{array}{l}\text { Closeness } \\
\text { to children } \\
\text { school } \\
\%(\text { Rank) }\end{array}$ & $\begin{array}{l}\text { Low } \\
\text { rent } \\
\% \\
\text { (Rank) }\end{array}$ & $\begin{array}{l}\text { Low } \\
\text { Income } \\
\text { \%(Rank) }\end{array}$ & $\begin{array}{l}\text { Family } \\
\text { affinity } \\
\text { \%(Rank) }\end{array}$ & $\begin{array}{l}\text { Well } \\
\text { planned } \\
\text { community } \\
\%(\text { Rank) }\end{array}$ & $\begin{array}{l}\text { Portion } \\
\text { of family } \\
\text { land } \\
\% \text { (Rank) }\end{array}$ \\
\hline 1 & Agege & $21.5(1)$ & $17.0(4)$ & $17.0(4)$ & $21.5(1)$ & $1.0(7)$ & $18.0(3)$ & - & $4.0(6)$ \\
\hline 2 & Ajeromi-Ifelodun & $18.8(1)$ & $14.1(5)$ & $13.5(6)$ & $18.8(1)$ & $15.7(4)$ & $17.6(3)$ & - & $1.6(7)$ \\
\hline 3 & Alimosho & $16.8(1)$ & $14.4(3)$ & $14.7(2)$ & $4.4(6)$ & $11.7(2)$ & $6.0(5)$ & - & $2.2(7)$ \\
\hline 4 & Amuwo-Odofin & $30.8(2)$ & $42.0(1)$ & $26.9(3)$ & $8.0(6)$ & $21.4(4)$ & $10.9(5)$ & - & - \\
\hline 5 & Apapa & $22.4(1)$ & $10.7(5)$ & $20.1(4)$ & $20.6(3)$ & $22.4(1)$ & $2.3(6)$ & $1.4(7)$ & - \\
\hline 6 & Eti-Osa & $26.8(1)$ & $7.8(6)$ & $25.5(2)$ & $9.8(5)$ & $5.9(7)$ & $13.7(3)$ & $10.5(4)$ & $2.2(8)$ \\
\hline 7 & Ifako-Ijaiye & $20.5(1)$ & $7.8(6)$ & $15.3(4)$ & $20.5(1)$ & $20.5(1)$ & $14.0(5)$ & - & $1.3(7)$ \\
\hline 8 & Ikeja & $19.1(2)$ & $27.3(1)$ & $13.4(5)$ & $16.0(4)$ & $16.5(3)$ & $6.2(6)$ & $1.5(7)$ & - \\
\hline 9 & Kosofe & $13.9(4)$ & $18.3(2)$ & $16.1(3)$ & $13.9(4)$ & $30.0(1)$ & $7.8(6)$ & - & - \\
\hline 10 & Lagos Island & $22.9(1)$ & $20.5(3)$ & $16.2(4)$ & $21.4(2)$ & $1.4(7)$ & $16.2(4)$ & $1.4(7)$ & $4.0(6)$ \\
\hline 11 & Lagos Mainland & $17.8(1)$ & $16.8(3)$ & $17.8(1)$ & $16.2(4)$ & $15.9(5)$ & $13.4(6)$ & $2.2(7)$ & - \\
\hline 12 & Mushin & $17.2(2)$ & $16.9(4)$ & $14.9(5)$ & $17.2(2)$ & $19.3(1)$ & $14.5(6)$ & - & - \\
\hline 13 & Ojo & $20.7(2)$ & $27.7(1)$ & 19.9 (4) & $20.7(2)$ & $15.9(5)$ & $14.1(6)$ & - & $0.8(7)$ \\
\hline 14 & Oshodi-Isolo & $12.2(5)$ & $20.0(1)$ & $19.6(2)$ & $12.2(5)$ & $19.6(2)$ & $16.5(4)$ & - & - \\
\hline 15 & Shomolu & $17.5(2)$ & $13.5(6)$ & $16.3(4)$ & $17.5(2)$ & $17.9(1)$ & $16.3(4)$ & - & $1.2(7)$ \\
\hline \multirow[t]{2}{*}{16} & Surulere & $18.5(2)$ & $10.6(4)$ & $3.2(7)$ & $19.9(1)$ & $15.9(3)$ & $8.6(5)$ & $3.3(6)$ & $1.1(8)$ \\
\hline & Total & 317.4 & 285.4 & 270.4 & 258.6 & 251.0 & 196.1 & 20.3 & 18.4 \\
\hline
\end{tabular}

\subsection{Urban Development in Flood-Prone Areas}

The nature of development in flood-prone areas in the Lagos metropolis revealed contiguous buildings with inadequate setbacks among them and between adjoining roads/streets, canals and lagoons. Most disturbing were developments in wetlands, gorges, canals and lagoons. These water bodies naturally connected with one another, such that disturbance in one affects the others. There is disruption or disturbance to the free flow of stream water each time there is rainfall, thereby causing inundation in the metropolis. Therefore, this study investigated whether or not development was continuing or had seized in flood-prone communities and also analysed the extent of urban development within floodplains in Lagos metropolis.

Table 7 presents the statuses of urban development across the LGAs, as obtained through checklist during the field survey. Development was ongoing in 10 out of the 16 metropolitan LGAs, as shown in Plate 3, where building foundations were being laid in flood-prone areas at Muwo, in Ojo LGA. Flood-prone areas were fully developed in Lagos Island, Lagos Mainland, Mushin, Oshodi-Isolo, Shomolu and Surulere LGAs. This corroborated the status of development in wetlands reported in Taiwo (2009).

Remote sensing and GIS analysis carried out revealed (Table 7) that urban development in flood-prone areas in the metropolis of Lagos in 1990 was $9.3 \mathrm{~km}^{2}(0.7 \%)$, development in non-flood-prone areas was $359.05 \mathrm{~km}^{2}$ (30.7\%), and vegetation cover was $802.93 \mathrm{~km}^{2}$ (68.6\%) (Figure 2). In the year 2000, vegetation cover reduced to $618.68 \mathrm{~km}^{2}(52.8 \%)$, while development in flood-prone and non-flood-prone areas increased to $10.50 \mathrm{~km}^{2}(0.9 \%)$ and $542.10 \mathrm{~km}^{2}(46.3 \%)$, respectively (Figure 3). The trend continued in the year 2014, as development in flood-prone and non-flood prone areas increased to $17.80 \mathrm{~km}^{2}(1.6 \%)$ and $892.90 \mathrm{~km}^{2}(76.2 \%)$, while vegetation cover reduced to $260.58(22.2 \%) \mathrm{km}^{2}$ (Figure 4). The results showed the trend in continuous development of flood-prone and vegetated areas in utter disregard for urban development regulations. Participant observation 
revealed that development in floodplains clogged stormwater drainage channels and other hydraulic infrastructures each time there was precipitation and caused flooding in metropolitan Lagos.

Table 7. Nature of development in flood-prone areas in the Lagos Metropolis, Nigeria

\begin{tabular}{|c|c|c|}
\hline Development in 1990 & Area $\left(\mathrm{Km}^{2}\right)$ & $\%$ of development of total land area \\
\hline Development in flood-prone area & 9.30 & 0.7 \\
\hline Development in non-flood-prone area & 359.05 & 30.7 \\
\hline Vegetation cover & 802.93 & 68.6 \\
\hline Total land area & 1171.28 & 100.0 \\
\hline \multicolumn{3}{|l|}{ Development in 2000} \\
\hline Development in flood-prone area & 10.50 & 0.9 \\
\hline Development in non-flood-prone area & 542.10 & 46.3 \\
\hline Vegetation cover & 618.68 & 52.8 \\
\hline Total land area & 1171.28 & 100.0 \\
\hline \multicolumn{3}{|l|}{ Development in 2014} \\
\hline Development in flood-prone area & 17.80 & 1.6 \\
\hline Development in non-flood-prone area & 892.90 & 76.2 \\
\hline Vegetation cover & 260.58 & 22.2 \\
\hline Total land area & 1171.28 & 100.0 \\
\hline
\end{tabular}

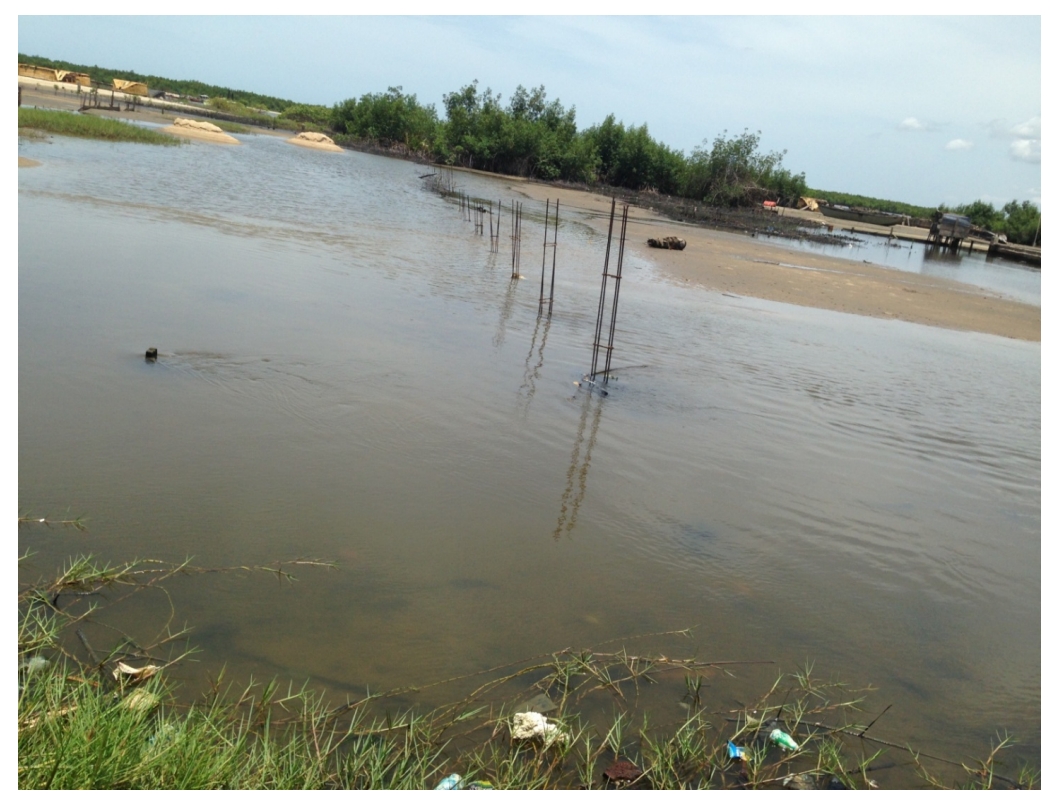

Plate 3. Reinforced columns for residential development erected in flood-prone area at Muwo, Ojo LGA 


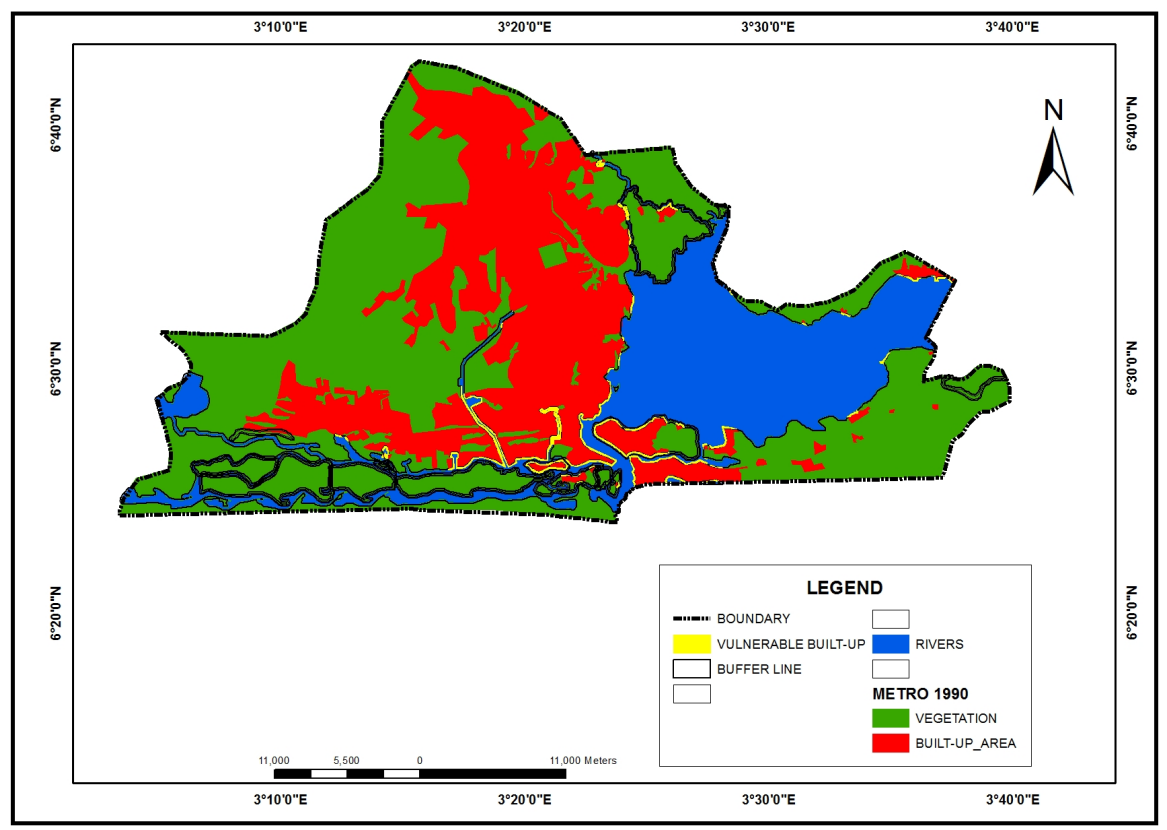

Figure 2. Urban Development in 1990

Source: Authors' analysis, 2014

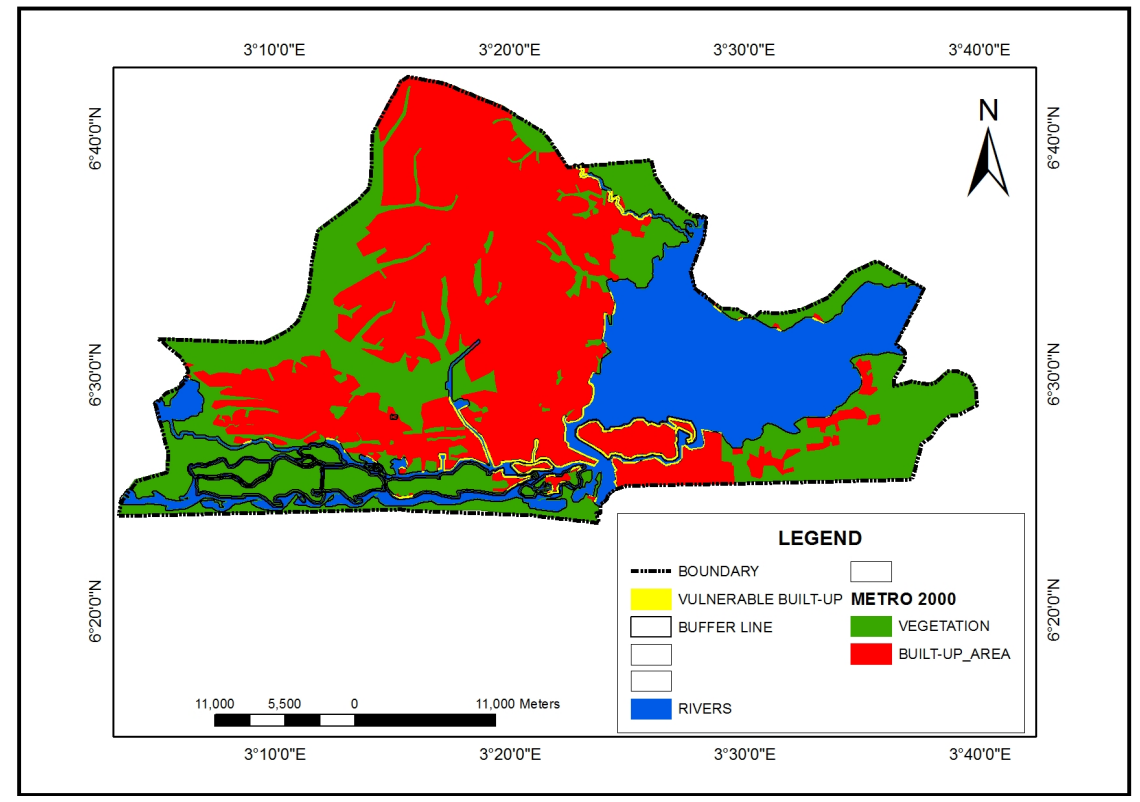

Figure 3. Urban Development in 2000

Source: Authors' analysis, 2014 


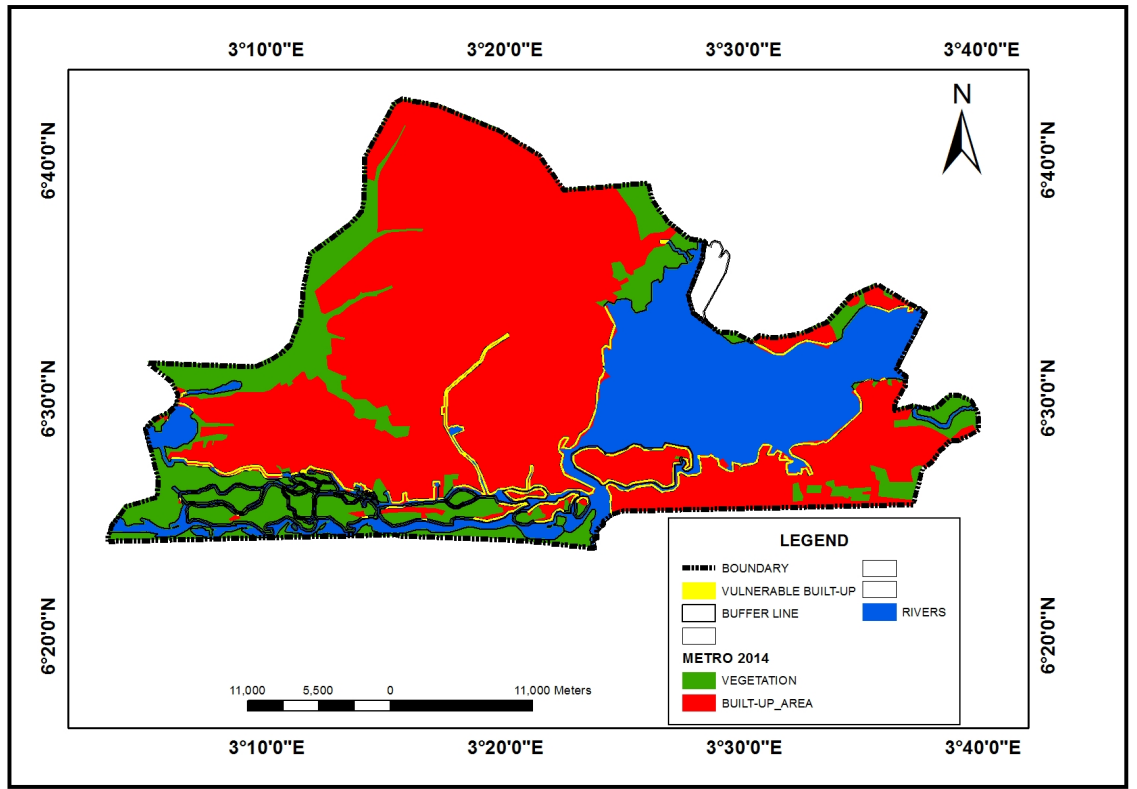

Figure 4. Urban Development in 2014

Source: Authors' analysis, 2014

\section{Summary and Conclusion}

The majority of the people inhabiting floodplains in metropolitan Lagos was poor, earning below $\$ 18,000$ per month, had secondary school education, and were into trading. These made them to occupy poor-low-rent buildings, with inferior materials, erected in the most precarious portions (floodplains) close to city centres since the late 1980s. The predominant reasons for living in floodplains in metropolitan Lagos in order of significance were closeness to place of work, nearness to market, closeness to children's schools, low rent, low income, and family affinity. Urban development in flood-prone areas increased from $9.3 \mathrm{~km}^{2}$ in 1990 to $10.50 \mathrm{~km}^{2}$ in 2000 and $17.80 \mathrm{~km}^{2}$ in 2014. The flooding of 2011, that killed 25 people displaced 5,393 households and destroyed an estimated $\$ 100$ billion worth of property, coincided with the period when physical development in flood-prone areas covered about $15.50 \mathrm{~km}^{2}$. The continuous physical development in flood-prone areas in metropolitan Lagos exposed residents to flood risks. The trend will not only increase the frequency of flooding and associated loss, but also make flood control and management difficult. The development of floodplains in violation of physical development control regulations is one of the causative factors of perennial flooding in metropolitan Lagos.

\subsection{Recommendations}

The Office of the Surveyor General of Lagos State should produce flood-risk maps indicating areas vulnerable to flood in the Lagos metropolis and make the maps readily available to the public for their information and necessary actions against physical developments in flood-prone areas.

Owing to the metropolitan nature of Lagos, that is associated with increasing population and housing shortages, the floodplains should be redesigned by the Ministry of Physical Planning and Urban Development (MPPUD) to accommodate adequate stormwater sewer and low-cost buildings that are flood-resistant. The building code for the flood-prone areas should be reviewed by the MPPUD to encourage and facilitate the development of flood-resistant buildings with consideration for appropriate construction materials and techniques that can prevent flood damage. The "houses living with floods" designed by the UN-HABITAT (Jah Jha, Bloch; \& Lamond, 2012) is suitable for the flood-hazard areas of the Lagos metropolis. Appropriate guidelines for integrating flood-risk into landuse planning, building construction and related physical development should be enacted and diligently implemented.

The low-income status of the majority of residents in the flood-prone areas requires that the Lagos State Government should assist in the provision of subsidies to facilitate their access to low-cost flood-resistant buildings that are raised above the regular flood level. This will enable the poor to continue to play active roles 
in the informal sectors of the city economies, enjoy easy access to their places of work, be close to their children's schools, and maintain unflinching affinity with their relations. To achieve this, partnership should be made with private developers who could finance the low-cost housing and let them to the poor at affordable rates. Enumeration of the people currently residing in the floodplains should be undertaken by the Lagos State Government in order not to exclude them in the implementation process. In the interim, the MPPUD should identify suitable areas that can be used for temporary shelters (camps) during flooding in the metropolis and communicate such to the people inhabiting the floodplains. This will go a long way in saving lives and reducing exposure to risks of flood in metropolitan Lagos.

\section{Acknowledgements}

The authors would like to thank the International Development Research Centre (IDRC) for financing this study through the Coastal City at Risk Project (CCaR) Lagos; and Dr. Ibidun O. Adelekan, Department of Geography, University of Ibadan for her support during the research. The incisive comments of Professors S. O. Fadare and Leke Oduwaye on the initial draft of this paper are also acknowledged.

\section{References}

Abiodun, J. A. (1997). The challenges of growth and development in metropolitan Lagos. In C. Rakodi (Ed.), The urban challenge in Africa: growth and management of its large cities (pp. 105-125). Tokyo-New York-Paris: Oxford University Press.

Action Aid. (2006). Climate change, urban flooding and the rights of the urban poor in Africa: Key findings from six African cities. London: Action Aid International.

Adelekan, I. O. (2012). Lagos city report. A paper presented at 2012 Advanced Institute on Data for Coastal Cities at Risk held in Taipei, Taiwan, 22-27 October.

Akanni, O., \& Bilesanmi, L. (2011, July 10). Flood: Lagos residents forced to relocate...Drowning teenager rescued. In Vanguard: Towards a Better Life for the People. Vanguard Media Limited: Lagos, p. 20.

Ayeni, B. (1979). Concepts and techniques in urban analysis. London: Croom Helm.

Ayeni, B. (1981). Lagos. In M. Pacione (Ed.), Problems and Planning in Third World Cities (pp. 127-155). London: Croom Helm.

Ayoade, J. O. (2006). Meteorological hazards and their impact on the Nigerian urban environment. In F. A. Ivbijaro, F. Akintola, \& R. U. Okechukwu (Eds.), Sustainable Environmental Management in Nigeria (pp. 61-83). Ibadan: Mattivi Productions.

Boamah, S. A., Armah, F. A., Kuuire, V. Z., Ajibade, I., Luginaah, I., \& McBean, G. (2015). Does previous experience of floods stimulate the adoption of coping strategies? Evidence from cross sectional surveys in Nigeria and Tanzania. Environments, 2, 565-585. https://doi.org/10.3390/environments2040565

Brooks, A. (2014). What is urban development? Retrieved February 1, 2014, from http://www.ehow.com/about_4728387_what-urban-development.html

Burgess, E. W. (1923). The growth of the city: An introduction to a research project. Proceedings of the American Society, 18, 85-97.

Collins English dictionary. (2014). Urban development. Retrieved February 1, 2014 from http://www.collinsdictionary.com/dictionary/english/urban-development

Deng, J. S., Wang, K., Hong, Y., \& Qi, J. G. (2009). Spatio-temporal dynamics and evolution of land use change and landscape pattern in response to rapid urbanization. Landscape and Urban Planning, 92, 187-198. https://doi.org/10.1016/j.landurbplan.2009.05.001

Etuonovbe, A. K. (2011, May). The devastating effect of flooding in Nigeria. Paper presented at FIG Working Week. Bridging the gap between Cultures, Marrakech, Morocco.

Hallegatte, S., Green, C., Nicholls, R. J., \& Corfee-Morlot, J. (2013). Future flood losses in major coastal cities. Nature and Climate, 3, 802-806. https://doi.org/10.1038/nclimate1979

Harris, C. D., \& Ullman, E. L. (1945). The nature of cities. Annals of the American Academy of Political and Social Sciences, 242, 7-17. https://doi.org/10.1177/000271624524200103

Hsiang-Leng, C., Hsing-Fu, K., \& Ko-Wan, T. (2013, September). The relation between flood probability and environmental transformation efficiency of urban development. Paper presented at International Conference on Flood Resilience: Experiences in Asia and Europe, Exeter, United Kingdom. 
Ijigah, E., \& Akinyemi, T. A. (2015). Flood disaster: An empirical survey of causative factors and preventive measures in Kaduna, Nigeria International Journal of Environment and Pollution Research, 3(3), 53-66.

Jha, A. K., Bloch, R., \& Lamond, J. (2012). Cities and flooding: A guide to integrate urban flood risk management for the $21^{\text {st }}$ century. Washington, DC: The World Bank and Global Facility for Disaster Reduction and Recovery (GFDRR). https://doi.org/10.1596/978-0-8213-8866-2

Lagos State Government. (2014). The growth of Lagos. Retrieved February 1, 2014, from http://www.lagosstate.gov.ng

National Population Commission (NPC). (1991). National Population Census of Nigeria. Abuja: NPC.

National Population Commission (NPC). (2006). National Population Census of Nigeria. Abuja: NPC.

National Population Commission (NPC). (2010). Population and Housing Census: Priority Table Volume III. Abuja: National Population Commission of Nigeria.

Nkwunonwo, U. C. (2017). Assessment of social vulnerability for efficient management of urban pluvial flooding in the Lagos metropolis of Nigeria. Journal of Environmental Studies, 3(1), 1-11. https://doi.org/10.13188/2471-4879.1000014

Odumosu, T. (1999). Location and regional setting of Lagos State. In Balogun T., Odumosu, T., \& K. Ojo (Eds.), Lagos State in Maps (pp. 228-229). Ibadan; Rex Charles.

Okude, A. S., \& Ademiluyi, I. A. (2006). Implications of the changing pattern of land cover of the Lagos coastal area of Nigeria, American-Eurasian Journal of Scientific Research, 1(1), 31-37.

Oni, S. I. (2003, November). Towards sustainable coastal hazard management in Nigeria. Paper presented at International Conference on Estuaries and Coasts, Hangzhou, China.

Ouikotan, R. B, van der Kwast, J., Mynett, A., \& Afouda, A. (2017). Gaps and challenges of flood risk management in West African coastal cities. World Water Congress XVI, International Water Recourses Association (IWRA), Cancun, Quintana Roo, Mexico, 29 May - 3 June. 1-12.

Taiwo, O. J. (2009). Socioeconomic correlates of the spatio-temporal variations in wetland loss in Lagos State, Nigeria (Unpublished $\mathrm{PhD}$ thesis). University of Ibadan, Nigeria.

United Nations, Department of Humanitarian Affairs (UNDHA). (2006). Floods: People at risk, strategies for prevention. Geneva: United Nations.

United Nations. (2014). World urbanization prospects (CD-ROM Edition). Population Division of the Department of Economic and Social Affairs, United Nations.

Yamane, T. (1967). Statistics: An introductory analysis (2nd ed.). New York: Harper and Row.

\section{Copyrights}

Copyright for this article is retained by the author(s), with first publication rights granted to the journal.

This is an open-access article distributed under the terms and conditions of the Creative Commons Attribution license (http://creativecommons.org/licenses/by/4.0/). 